\title{
Faktor-Faktor yang Memengaruhi Daya Saing Industri Unggas Ayam Kampung (Studi Kasus PT Dwi dan Rachmat Farm, Bogor)
}

\author{
Factors that Affecting Competitiveness of Poultry Industry Kampong Chicken \\ (Case Study PT Dwi and Rachmat Farm, Bogor)
}

Siti Aedah ${ }^{1 *}$, M.H. Bintoro Djoefrie ${ }^{2}$, dan Gendut Suprayitno ${ }^{3}$

\author{
${ }^{1}$ Kementerian Koperasi dan UKM RI \\ Jl. HR Rasuna Said, Kav.3-4 Kuningan, Jakarta Selatan \\ Telp. 021-5204366-74, 5299277, 52992999, 52992885, Fax. 021-5204383 \\ ${ }^{2}$ Departemen Agronomi dan Hortikultura, Fakultas Pertanian, IPB \\ Jl. Kamper Kampus IPB Dramaga Bogor 16680 \\ 3Program Studi Magister Pengembangan Industri Kecil Menengah, Sekolah Pascasarjana, IPB \\ Jl. Raya Pajajaran, Kampus IPB Baranangsiang, Bogor 16112
}

\begin{abstract}
ABSTRAK
Industri perunggasan di Indonesia sering mengalami pasang surut beberapa tahun terakhir ini. Rentannya usaha ayam ras pedaging terhadap berbagai gejolak membuka peluang untuk mengembangkan usaha unggas lokal seperti ayam kampung yang saat ini popularitasnya semakin meningkat dibandingkan dengan daging unggas lainnya. Industri unggas ayam kampung sangat prospektif, mengingat kebutuhan akan protein hewani bersumber dari daging unggas semakin meningkat dan didukung oleh perkembangan industri kuliner yang pesat saat ini. Tujuan penelitian ini mengidentifikasi faktor-faktor yang memengaruhi daya saing industri unggas ayam kampung. Metode penelitian deskriptif, diolah dan dianalisis menggunakan Model Berlian Porter. Hasil penelitian menunjukkan faktor-faktor yang memengaruhi daya saing industri unggas ayam kampung yang mempunyai nilai atribut paling tinggi yaitu: sumber daya manusia atau SDM, jumlah pembeli dan tingkat pertumbuhan pembeli, usaha pembibitan, industri produk pengganti, roadmap dan bussines plan pengembangan ayam kampung, iklim usaha yang kondusif. Atribut yang paling rendah yaitu infrastruktur, sumber daya modal, integrasi industri pemasok dan fasilitasi ekspor.
\end{abstract}

Kata kunci: ayam kampung, daya saing, industri unggas

\section{ABSTRACT}

The poultry industry in Indonesia often experience ups and downs the last few years. The volatility of broiler effort to shocks opportunities to develop local businesses like poultry chicken that is currently growing in popularity compared with other poultry meat. Chicken poultry industry is highly prospective, given the need for animal protein derived from poultry meat is increasing and is supported by the rapid development of the culinary industry today. The purpose of this study to identify the factors affecting the competitiveness of the poultry industry chicken. Descriptive research method, processed and analyzed using the Porter Diamond Model. The results showed the factors that influence competitiveness the poultry industry kampong chicken which has the highest attribute values, namely: human resources, the number of buyers and buyer growth rate, breeding, industrial replacement products, roadmap and business plan development of chicken, a conducive business climate. Attributes of the lowest infrastructure, capital resources, integration of industry suppliers and facilitation of exports.

Key words: competitiveness, kampong chiken, poultry industry

\footnotetext{
*) Korespondensi:

Jl. HR Rasuna Said, Kav.3-4 Kuningan, Jakarta Selatan; email: sitiaedah@gmail.com
} 


\section{PENDAHULUAN}

Industri merupakan sektor sekunder dalam pembangunan ekonomi negara yang berperan dalam menentukan pendapatan per kapita yang bersumber dari persentase kontribusinya terhadap produk domestik bruto (PDB). Industri dapat dijadikan indikator utama perkembangan ekonomi makro, yang dicirikan oleh terpenuhinya kebutuhan masyarakat oleh produk yang dihasilkan, baik barang konsumsi, kemampuan membuat bahan baku dan bahan penolong, komponen dan suku cadang untuk keperluan dalam dan luar negeri (pasar ekspor), tingkat persaingan yang dihadapi (misal, keunggulan komparatif atau kompetitif) dalam ukuran berupa pendapatan yang naik lebih cepat dari rataan (Hubeis, 2013).

Upaya percepatan pembangunan sektor pertanian, terutama yang berkaitan dengan pangan merupakan hal mutlak dilakukan saat ini. Pembangunan sub sektor peternakan sebagai salah satu penghasil bahan pangan hewani perlu didukung bersama. Sebagai ilustrasi data statistik peternakan (Tabel 1) menunjukkan bahwa pemenuhan daging tahun 2015 sebagian besar berasal dari ayam ras pedaging 53,13\%, ayam buras (ayam Kampung, dan ayam lokal) 10,25\%, daging sapi hanya $17,11 \%$ terhadap total produksi daging nasional (BPS, 2016).

Industri perunggasan di Indonesia sering mengalami pasang surut. Pada awal tahun 1998, saat krisis ekonomi dan moneter banyak bisnis perunggasan yang bangkrut. Wabah flu burung (Avian Influenza) yang menurunkan gairah peternakan unggas di Indonesia. Selain itu kasus impor leg quarter dari Amerika Serikat dan masalah Pajak Pertambahan Nilai (PPN) merupakan permasalahan bisnis perunggasan (Utoyo, 2006).
Tabel 1. Produksi daging berdasarkan jenis ternak pada Tahun 2015

\begin{tabular}{clrr}
\hline No. & Jenis Ternak & $\begin{array}{c}\text { Daging } \\
\text { (Ton) }\end{array}$ & $\begin{array}{r}\text { Persentase } \\
(\%)\end{array}$ \\
\hline 1. & Sapi Potong & 523.927 & 17,11 \\
2. & Kerbau & 31.669 & 1,03 \\
3. & Kambing & 65.851 & 2,15 \\
4. & Domba & 40.950 & 1,34 \\
5. & Babi & 319.114 & 10,42 \\
6. & Kuda & 2.449 & 0,08 \\
7. & Ayam Buras & 313.996 & 10,25 \\
8. & Ayam Ras Petelur & 95.646 & 3,12 \\
9. & Ayam Ras Pedaging & 1.627 .106 & 53,13 \\
10. & Itik & 34.845 & 1,14 \\
11. & Kelinci & 554 & 0,02 \\
12. & Burung Puyuh & 993 & 0,03 \\
13. & Merpati & 297 & 0,01 \\
14. & Itik Manila & 4.469 & 0,16 \\
\hline Ayam & Buras terdiri atas ayam Kampung dan & ayam
\end{tabular}

a Ayam Buras terdiri atas ayam Kampung dan ayam Lokal

Sumber: BPS 2016.

Rentannya usaha ayam ras pedaging terhadap berbagai gejolak membuka peluang untuk mengembangkan usaha unggas lokal seperti ayam kampung yang saat ini popularitasnya semakin meningkat dibandingkan daging unggas lainnya. Hal ini ditunjukkan dengan laju pertumbuhan produksi paling tinggi $5,49 \%$ seperti disajikan pada Tabel 2.

Sejalan dengan hal tersebut, arah kebijakan strategik pemerintah yang tertuang dalam Rencana Strategik (Renstra) Kementerian Pertanian Tahun 2015-2019, ayam lokal merupakan salah satu dari delapan komoditas peternakan yang akan dikembangkan dalam rangka pemenuhan kebutuhan daging, untuk memenuhi kebutuhan pangan asal ternak menuju kedaulatan pangan nasional (Gambar 1).

Tabel 2. Produksi daging unggas secara nasional (ton) pada tahun 2011-2015

\begin{tabular}{|c|c|c|c|c|c|c|c|}
\hline \multirow{2}{*}{ No } & \multirow{2}{*}{ Jenis daging unggas } & \multicolumn{5}{|c|}{ Tahun } & \multirow{2}{*}{$\begin{array}{c}\text { Laju } \\
\text { Pertumbuhan } \\
(\%) \\
\end{array}$} \\
\hline & & 2011 & 2012 & 2013 & 2014 & 2015 & \\
\hline 1 & Ayam Buras & 264.795 & 267.492 & 319.599 & 297.663 & 313.996 & 5,49 \\
\hline 2 & Ayam Ras Petelur & 62.145 & 66.050 & 77.135 & 97.195 & 95.646 & $-1,59$ \\
\hline 3 & Ayam Ras Pedaging & 1.337 .911 & 1.400 .470 & 1.497 .873 & 1.544 .379 & 1.627 .106 & 5,36 \\
\hline 4 & Itik & 28.183 & 30.053 & 32.129 & 33.178 & 34.845 & 5,02 \\
\hline 5 & Burung Puyuh & 95 & 6.942 & 878 & 968 & 993 & 2,57 \\
\hline 6 & Merpati & 90 & 636 & 201 & 290 & 297 & 3,57 \\
\hline \multirow[t]{2}{*}{7} & Itik Manila & - & 3.558 & 4.024 & 4.807 & 4.969 & 3,39 \\
\hline & Total & 1.693 .219 & 1.775 .201 & 1.931 .839 & 1.978 .480 & 2.077 .852 & \\
\hline
\end{tabular}

Sumber: BPS, 2016. 


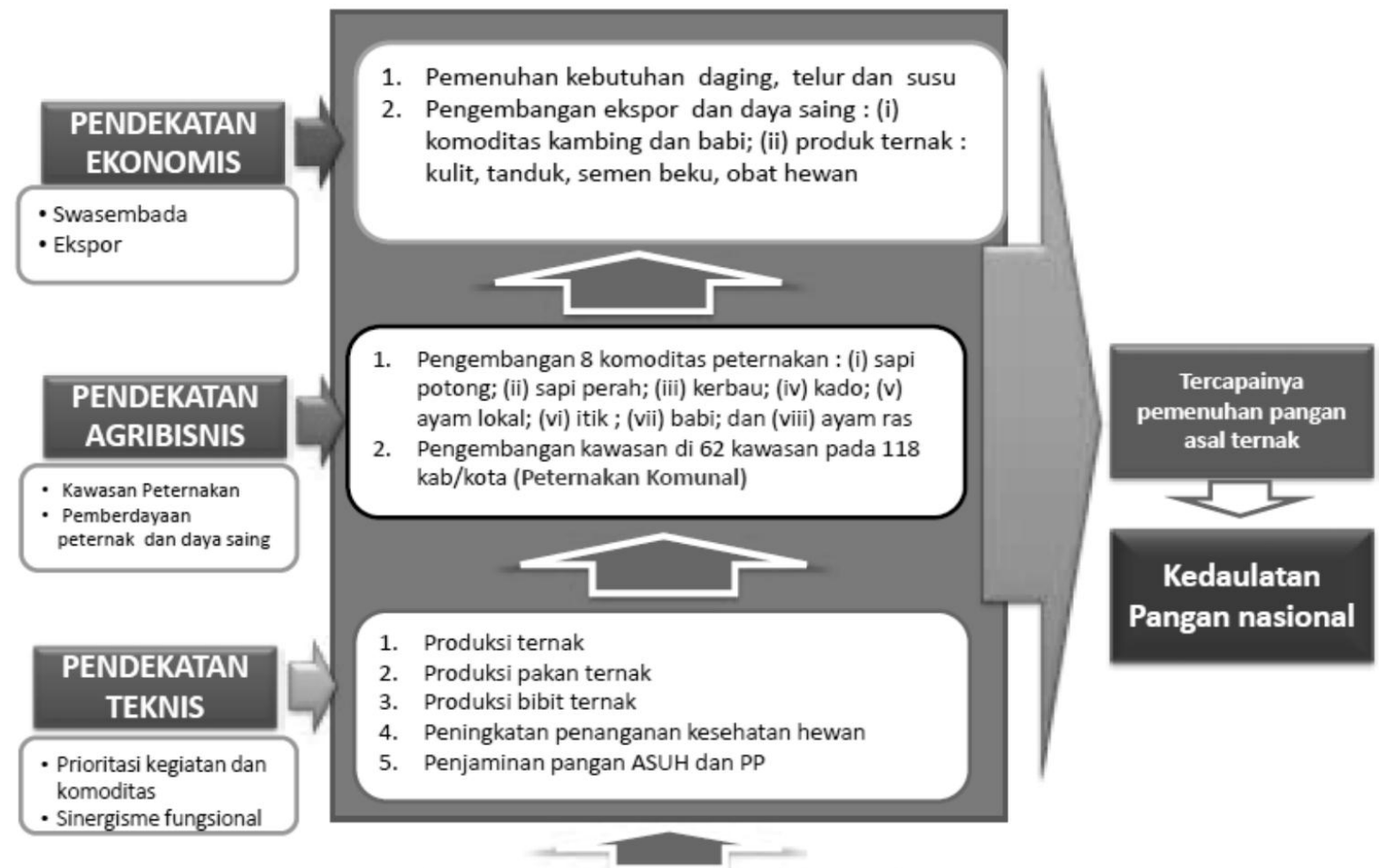

DUKUNGAN LINTAS SEKTOR

Sumber: Kementan, 2015.

Gambar 1. Langkah operasional peningkatan produksi daging

Peternakan ayam kampung yang dulu dipelihara secara ekstensif, kini dapat dipelihara secara intensif dengan masa pemeliharaan singkat. Balai Penelitian Ternak (Balitnak) Ciawi menseleksi ayam kampung selama enam generasi sejak tahun 1997. Ayam kampung tersebut dinamakan Ayam kampung KUB (Kampung Unggul Balitbang Pertanian). Ayam KUB merupakan salah satu ayam kampung unggulan hasil seleksi sebagai galur betina penghasil telur/DOC (Day Old Chiken) dan ayam Sentul merupakan sumber daya genetik ternak ayam asli dari Ciamis yang berpotensi untuk dijadikan galur jantan. Kedua galur ayam ini merupakan ayam asli Indonesia yang memiliki keragaman fenotipik berbeda (Sartika, 2013).

Keberadaan ayam kampung KUB membantu pencapaian target produksi daging unggas. Usaha ayam kampung juga dilindungi oleh pemerintah dari perusahaan besar. Pembibitan dan budidaya ayam buras, serta persilangannya diperuntukkan bagi koperasi dan usaha mikro, kecil dan menengah (UMKM) (Perpres No. 39/2014). Potensi lain ayam kampung merupakan unggas lokal yang mempunyai rasa yang khas, enak dan lezat, serta adanya tren konsumsi masyarakat terhadap produk sehat dan alami, mendorong tumbuhnya perkembangan kuliner ayam kampung.

Berdasarkan hal tersebut, peternakan ayam kampung sangat prospektif, mengingat kebutuhan akan protein hewani bersumber dari daging unggas semakin meningkat dan didukung oleh perkembangan industri kuliner yang pesat saat ini. Hasil penelitian Saptana dan Sartika (2014) menunjukkan usaha ternak ayam kampung memberikan keuntungan cukup memadai.

Usaha peternakan di berbagai negara dunia sudah mengarah ke industri sehingga usaha peternakan harus mampu bersaing agar tetap bertahan. Di Indonesia, terdapat banyak peternakan dilakukan dalam skala industri tetapi masih banyak juga dijumpai peternakan subsisten. Oleh karena itu, hanya peternak kecil yang memelihara ternak 1-2 unit dengan motivasi untuk simpanan dan sosial pada akhirnya tidak mempunyai daya saing (Tangendjaja, 2016a). Meskipun industri unggas terus berkem-bang tetapi industri di Indonesia masih belum mampu berkompetisi dengan industri ungags di negara lain di Asean (Tangendjaja, 2016b).

Tujuan penelitian mengidentifikasi faktorfaktor yang memengaruhi daya saing industri unggas ayam kampung. 


\section{METODE PENELITIAN}

Penelitian ini dilaksanakan di PT DnR Farm, Bogor dari bulan Januari hingga Juni 2016. Metode penelitian yang digunakan adalah metode penelitian deskriptif. Proses pengambilan data dilakukan dengan cara survei, observasi dan wawancara menggunakan kuesioner. Narasumber terdiri dari lima orang, yaitu dari Dinas Peternakan Kabupaten Bogor, Himpuli (Himpunan Pengusaha Unggas Lokal Indonesia), PT DnR Farm, Peneliti Balitnak, dan Kementerian Pertanian. Pengolahan dan analisis data menggunakan Model Berlian Porter.

\section{HASIL DAN PEMBAHASAN}

Penelitian ini mengidentifikasi mengidentifikasi faktor-faktor yang memengaruhi daya saing industri unggas ayam Kampung PT DnR Farm dengan menggunakan Porter's Diamond Model. Menurut Porter (1998) suatu negara memperoleh keunggulan daya saing atau competetive advantage (CA), jika perusahaan yang ada di negara tersebut kompetetitif. Daya saing suatu negara ditentukan oleh kemampuan suatu industri dalam melakukan inovasi dan meningkatkan kemampuannya. Perusahaan memperoleh CA karena tekanan dan tantangan. Perusahaan menerima manfaat dari adanya persaingan di pasar domestik, perusahaan domestik yang agresif dan pasar lokal yang memiliki permintaan tinggi. Perbedaan dalam nilai-nilai nasional, budaya, struktur ekonomi, institusi dan sejarah memberikan kontribusi pada keberhasilan persaingan.

Teori Berlian Porter (1998) terdiri atas empat determinan (faktor-faktor yang menentukan) National Competitive Advantage (NCA). Faktor-faktor tersebut yaitu: faktor kondisi, kondisi permintaan, industri terkait dan industri pendukung, serta persaingan industri. Selain keempat faktor, terdapat dua faktor yang memiliki pengaruh pada kedua determinan tersebut, yaitu pemerintah dan kesempatan.

Berdasarkan hasil kuesioner terhadap lima narasumber, didapatkan atribut yang memiliki nilai tertinggi yaitu sumber daya manusia (SDM) bernilai $(4,00)$, sumber daya alam (SDA) dan lingkungan $(4,00)$, jumlah pembeli dan tingkat pertumbuhan pembeli $(4,00)$, usaha pembibitan $(4,0)$, industri produk pengganti $(4,0)$, program dan kebijakan pengembangan ayam kampung
$(4,0)$, dan iklim usaha kondusif $(4,0)$. Atribut terendah adalah infrastruktur $(2,8)$, sumber daya modal (2,8), integrasi industri pemasok $(2,8)$, perusahaan sejenis dengan kapasitas lebih besar $(2,8)$ dan fasilitasi ekspor $(2,8)$. Nilai atribut dapat dilihat pada Tabel 3, dan ilustrasi model daya saing industri unggas ayam kampung berdasarkan model berlian Porter pada Gambar 1.

1. Faktor kondisi

Faktor kondisi mengacu pada input yang digunakan oleh industri perunggasan untuk menghasilkan produk berdaya saing. Unsurunsur penting yang menjadi faktor kondisi dalam industri perunggasan adalah infrastruktur, SDM, sumber daya modal, SDA dan lingkungan, serta teknologi.

a. Infrastruktur

Kondisi infrastruktur berupa sarana prasarana jalan, moda transportasi, bangunan kandang, air bersih dan energi di lokasi PT DnR Farm saat ini yang tersedia dengan baik dan memadai. Nilai atribut infrastruktur memiliki nilai rendah $(2,8)$ dimungkinkan karena kondisi saat ini infrastruktur sudah tersedia dengan baik dan bukan merupakan permasalahan utama.

b. SDM

SDM memiliki peranan sangat penting dalam daya saing baik bersifat global, nasional maupun perusahaan. Dalam Global Competitiveness Report 2015-2016 World Economic Forum $(W E F)$, peringkat Indonesia turun dari urutan ke-34 menjadi ke-37 dari 140 negara (WEF 2015).

Untuk memenuhi kebutuhan SDM di PT DnR Farm di rekrut karyawan sesuai kebutuhan dan keahlian. Berdasarkan Tabel 3, SDM merupakan faktor yang sangat memengaruhi keunggulan bersaing industri unggas ayam kampung $(4,0)$.

Faktor SDM merupakan faktor terpen-ting dalam penentu daya saing UKM. Faktor SDM meliputi keahlian atau kapasitas dari para pekerja dan pengusaha/pemilik usaha. Keahlian pekerja merujuk pada kapasitas terkait teknik produksi, teknik pemasaran, serta kapasitas penelitian dan pengembangan (litbang). Keahlian pengusaha mencakup wawasan bisnis, terutama wawasan bisnis yang dijalankan dan lingkungan eksternalnya (Bappenas 2013). Menurut Shadid (2007), kreativitas dan wawasan bisnis seorang pengusaha dapat membentuk kemampuan pengusaha melakukan inovasi. 
c. Sumber daya modal

Modal pada umumnya menjadi permasalahan klasik bagi industri kecil menengah (IKM). PT DnR Farm tidak menggunakan modal dari perbankan. PT DnR Farm dalam melaksanakan usahanya menggunakan modal sendiri, dan untuk memenuhi kebutuhan permodalan lainnya menjalankan kemitraan dengan peternak mitra atau lembaga lain sesuai akad musyarakah. Salah satunya dengan Koperasi Pondok Pesantren Darul Fallah bekerjasama dalam hal penyediaan lahan, bangunan dan peralatan Rumah Potong Unggas (RPU).

Tabel 3. Faktor yang memengaruhi daya saing industri unggas ayam kampung

\begin{tabular}{|c|c|c|c|c|c|c|}
\hline \multirow{2}{*}{ No } & \multirow{2}{*}{ Atribut } & \multicolumn{4}{|c|}{ Nilai } & \multirow{2}{*}{ Rataan } \\
\hline & & 1 & 2 & 3 & 4 & \\
\hline \multicolumn{7}{|c|}{ Faktor Kondisi } \\
\hline 1 & Infrastruktur & 0 & 1 & 4 & 0 & 2,80 \\
\hline 2 & SDM & 0 & 0 & 0 & 5 & 4,00 \\
\hline 3 & Sumberdaya modal & 0 & 1 & 4 & 0 & 2,80 \\
\hline 4 & SDA dan lingkungan & 0 & 0 & 3 & 2 & 3,40 \\
\hline 5 & Teknologi & 0 & 0 & 2 & 3 & 3,60 \\
\hline \multicolumn{7}{|c|}{ Kondisi Permintaan } \\
\hline 6 & Jumlah pembeli dan tingkat pertumbuhan pembeli & 0 & 0 & 0 & 5 & 4,00 \\
\hline 7 & Bermunculannya kuliner ayam kampung & 0 & 0 & 2 & 3 & 3,60 \\
\hline 8 & Harga jual ayam kampung relatif tinggi dan stabil & 0 & 0 & 1 & 4 & 3,80 \\
\hline 9 & Popularitas ayam kampung budidaya & 0 & 0 & 2 & 3 & 3,60 \\
\hline 10 & Prefensi Konsumen & 0 & 0 & 1 & 4 & 3,80 \\
\hline \multicolumn{7}{|c|}{ Industri terkait dan industri pendukung } \\
\hline 11 & Perusahaan pakan ternak & 0 & 0 & 1 & 4 & 3,80 \\
\hline 12 & Perusahaan obat-obatan & 0 & 0 & 2 & 3 & 3,60 \\
\hline 13 & Usaha pembibitan & 0 & 0 & 0 & 5 & 4,00 \\
\hline 14 & Horeka (hotel restoran dan catering) & 0 & 0 & 1 & 4 & 3,80 \\
\hline 15 & Peternak mitra & 0 & 0 & 3 & 2 & 3,40 \\
\hline \multicolumn{7}{|c|}{ Persaingan Industri } \\
\hline 16 & Tingkat persaingan di industri perunggasan & 0 & 0 & 4 & 1 & 3,20 \\
\hline 17 & Strategi pesaing & 0 & 0 & 5 & 0 & 3,00 \\
\hline 18 & Integrasi industri pemasok & 0 & 1 & 4 & 0 & 2,80 \\
\hline 19 & Perusahaan sejenis dengan kapasitas besar dan lengkap & 0 & 1 & 4 & 0 & 2,80 \\
\hline 20 & $\begin{array}{l}\text { Industri produk pengganti seperti ayam petelur } \\
\text { pejantan, ayam super, ayam color bird }\end{array}$ & 0 & 0 & 0 & 5 & 4,00 \\
\hline \multicolumn{7}{|c|}{ Peran Pemerintah } \\
\hline 21 & Mengatur tata niaga yang fair & 0 & 0 & 1 & 4 & 3,80 \\
\hline 22 & Ketersediaan bibit ayam kampung & 0 & 0 & 1 & 4 & 3,80 \\
\hline 23 & $\begin{array}{l}\text { Roadmap dan bussines plan pengembangan ayam } \\
\text { kampung }\end{array}$ & 0 & 0 & 0 & 5 & 4,00 \\
\hline 24 & $\begin{array}{l}\text { Proteksi pasar dalam negeri dari ancaman produk } \\
\text { impor }\end{array}$ & 0 & 0 & 1 & 4 & 3,80 \\
\hline 25 & Fasilitasi ekspor & 0 & 1 & 4 & 0 & 2,80 \\
\hline \multicolumn{7}{|c|}{ Peran Kesempatan } \\
\hline 26 & Iklim usaha yang kondusif & 0 & 0 & 0 & 5 & 4,00 \\
\hline 27 & Kasus flu burung & 0 & 0 & 3 & 2 & 3,40 \\
\hline 28 & Gejolak industri ayam ras & 0 & 0 & 1 & 4 & 3,80 \\
\hline 29 & $\begin{array}{l}\text { Ditemukannya bibit ayam kampung dengan masa } \\
\text { panen lebih singkat }\end{array}$ & 0 & 0 & 1 & 4 & 3,80 \\
\hline 30 & $\begin{array}{l}\text { Proteksi ternak lokal terhadap perusahaan besar dan } \\
\text { Penanaman Modal Asing (PMA) }\end{array}$ & 0 & 0 & 2 & 3 & 3,60 \\
\hline
\end{tabular}


Program kemitraan dengan peternak mitra dinamakan RITA (Rekan Investasi Ternak Anda). RITA adalah program kerjasama kemitraan peternakan Ayam Kampung Asliyang kegiatan utamanya adalah membeli bibit Ayam Kampung, memeliharanya hingga layak jual, kemudian dan menjual di pasar. Pembagian hasil $40 \%$ untuk pemodal, serta $40 \%$ untuk pengelola (DnR Farm) dan $20 \%$ untuk pekerja kandang.

d. SDA dan lingkungan

SDA dan lingkungan memiliki peran penting dalam sebuah usaha, terutama usaha yang terkait dengan mahluk hidup. Keberhasilan sebuah usaha peternakan ayam dipengaruhi oleh SDA dan lingkungan (Tabel 3). Sejalan dengan hal tersebut lokasi PT DnR Farm terletak di daerah dataran tinggi Bogor. Kondisi tanah, air dan lingkungan mendukung. Sekitar lokasi peternakan terdapat beberapa peternakan ayam, pesawahan dan hortikultura.

e. Teknologi

Sumber daya ilmu pengetahuan dan teknologi (Iptek) sangat menentukan kemajuan suatu industri. Ketersediaan sumber-sumber pengetahuan dan teknologi dapat bersumber dari lembaga lain seperti perguruan tinggi, lembaga riset, literatur bisnis dan ilmiah, basis data, laporan penelitian, asosiasi, balai penelitian, serta sumber pengetahuan dan teknologi lainnya. PT DnR Farm melakukan kerjasama dengan Balitnak Ciawi dalam hal penyediaan bibit ayam KUB dan pelatihan inseminasi buatan (IB).

Teknologi berperan penting bagi keberlangsungan usaha budidaya ayam kampung. Proses pembibitan untuk menghasilkan DOC (day old chicken), sistem perkandangan (kandang inkubator, kandang panggung mini, dan kandang postal), perlengkapan pendukung seperti induk buatan (brooder), pelingkar (chick guard), tempat pakan (feeder), tempat minum (waterer), alat penyuci hama, alat penerangan, mesin tetas, alat kemasan, biosecurity, dan alat penampung limbah.

2. Faktor Permintaan

Faktor permintaan merupakan factor yang sangat penting dalam usaha. Tingginya permintaan akan mendorong perusahaan memproduksi produknya dalam jumlah banyak. Faktor-faktor yang berpengaruh nyata terhadap industri kecil (alas kaki) adalah modal sosial dan kondisi permintaan (Widyastutik et al. 2010).

a. Jumlah pembeli dan tingkat pertumbuhan pembeli

Kebutuhan daging ayam kampung dari tahun ke tahun di berbagai daerah mengalami peningkatan, perkembangan konsumsi ayam buras 0,54-0,56 kg/kapita/tahun (2010-2012), dan meningkat menjadi $0,57 \mathrm{~kg} / \mathrm{kapita} / \mathrm{tahun}$. Hal ini menunjukkan permintaan daging ayam kampung cukup tinggi.

b. Bermunculannya kuliner ayam kampung

Produk ayam kampung saat ini sedang digemari oleh penikmat kuliner. Rasanya yang khas serta adanya kesadaran masyarakat terhadap pola konsumsi makanan dan saat ini mendorong tumbuhnya kuliner ayam kampung.

c. Harga jual ayam kampung relatif tinggi dan stabil

Harga jual daging ayam kampung lebih mahal dibandingkan dengan daging ayam ras, di tingkat peternak harga ayam kampung pedaging berkisar Rp36.000/0,5-0,7kg, dan di Pasar Tradisional Rp70.000-90.000/kg.

d. Popularitas ayam kampung budidaya

Ayam kampung budidaya merupakan ayam kampung yang dipelihara secara intensif seperti ayam ras. Dengan ditemukannya Ayam KUB, maka beternak ayam kampung intensif semakin diminati. PT DnR Farm secara rutin menyelenggarakan pelatihan budidaya ayam kampung terhadap calon wirausaha baru.

e. Preferensi konsumen

Preferensi konsumen merupakan pilihan suka tidak suka seseorang terhadap produk yang dikonsumsi. Preferensi konsumen menunjukkan kesukaan konsumen dari berbagai pilihan yang ada. Preferensi konsumen terhadap ayam kampung cukup tinggi, mengingat konsumen menyukai ayam kampung karena rasanya yang khas, berbeda dengan ayam ras, sehingga pasar ayam kampung tersegmentasi.

3. Faktor Industri Terkait dan Industri Pendukung

Industri terkait merupakan industri terdekat yang secara langsung berhubungan dengan industri inti. Industri-industri yang secara langsung berkaitan dengan usaha budidaya ayam kampung adalah pemasok input dan bahan baku, serta retail dan food industry. Sementara industri pendukung terdiri dari lembaga-lembaga yang secara tidak 
langsung menyokong kelangsungan kegiatan usaha industri inti. Dalam bisnis ini, industri pendukung terdiri dari lembaga penelitian, asosiasi-asosiasi, lembaga pemerintah, dan lembaga-lembaga keuangan.

a. Perusahaan pakan ternak

Pakan merupakan komponen terbesar dalam pemeliharaan unggas termasuk ayam kampung. Usaha ayam ras merupakan usaha yang memiliki harga output dan input sangat sensitif, karena 60-80\% komponen usaha ayam ras berasal dari pakan ternak. Pakan ternak yang digunakan merupakan komponen biaya terbesar, dikarenakan bahan pakan ternak berasal dari jagung dan bungkil kedelai tergantung pada impor sehingga memiliki ketergantungan terhadap harga komoditas jagung dan kedelai internasional (Arli et al, 2012).

Pakan ayam kampung budidaya sama halnya dengan pakan ayam ras, diberikan sesuai dengan masa pemeliharaan (starter, grower dan layer) dan diberikan tambahan limbah makanan seperti sisa nasi rumah, sayuran dan ikan. Belum tersedianya pakan khusus bagi ayam kampung budidaya, menimbulkan ketergantungan perusahaan unggas ayam kampung terhadap perusahaan pakan ternak ayam ras menjadi sangat tinggi. PT DnR Farm masih tergantung dari perusahaan pakan ternak besar seperti PT Charoen Phokpan, PT Jafpa, dan PT Gold Coin.

b. Perusahaan obat-obatan

Ayam kampung dikenal memiliki daya tahan tubuh tinggi terhadap penyakit dibanding ayam ras. Namun demikian kewaspadaan terhadap penyakit yang biasa menyerang ayam harus diutamakan. Kewaspadaan meliputi pengobatan ayam yang sakit dengan tepat dan pencegahan, misalnya dengan vaksinasi, sanitasi dan pemeliharaan yang baik.

Suplemen, obat-obatan, vaksin, probiotik dan herbal merupakan usaha pendukung beternak ayam kampung. Suplemen, obatobatan, vaksin dan probiotik didapatkan dari perusahaan obat-obatan, sedangkan herbal merupakan jamu yang diracik sendiri. PT DnR Farm mendapatkan obat-obatan dari PT Romindo.

c. Usaha pembibitan

Pemerintah melalui Perpres Nomor 39/ 2014 mengatur bahwa pembibitan dan budidaya ayam buras, serta persilangannya diperuntukkan bagi koperasi dan UMKM.
Dengan adanya Perpres ini, perusahaan besar dan PMA tidak bisa masuk dalam usaha pembibitan ayam kampung. Sementara itu permintaan terhadap ayam kampung tinggi, disisi lain ketersediaan bibit ayam kampung terbatas. Saat ini perusahaan pembibitan ayam kampung besar adalah PT Ayam Kampung Indonesia (PT AKI), PT Warso Unggul Gemilang. Usaha pembibitan ini sangat penting keberadaannya mengingat pemerintah sedang mendorong usaha ternak ayam kampung tidak lagi skala rumah tangga kedalam skala industri.

d. Horeka (Hotel, Restoran, dan Katering)

Hotel, restoran, katering, ataupun rumah makan merupakan industri terkait yang sangat berperan dalam pemasaran produk ayam kampung. Horeka biasanya lebih selektif dalam menerima hasil panen, umumnya meminta ukuran tepat dan seragam.

e. Petani mitra

Peternak yang dijadikan mitra adalah para peternak yang berada di daerah sekitar peternakan dan peternak wirausaha baru hasil pelatihan dengan Komunitas Pengusaha Muslim Indonesia (KPMI).

4. Faktor Persaingan Industri

a. Tingkat persaingan di industri perunggasan

Tingkat persaingan industri terjadi apabila perusahaan menganggap para pesaingnya adalah semua perusahaan yang membuat produk atau kelas produk yang sama.

b. Strategi pesaing

Dalam strategi pemasaran perusahaan tidak hanya memperhatikan kebutuhan konsumen, tetapi juga strategi pesaing. Strategi pesaing diperlukan sebelum perusahaan melakukan strategi kompetitif. Untuk itu perusahaan harus memperoleh semua informasi tentang pesaingnya.

c. Integrasi industri pemasok

Kekuatan pemasok berpengaruh terhadap proses produksi sebuah industri, terlebih jika jumlah pemasok bahan baku tidak banyak, lokasi pemasok jauh, dan produk substitusi sangat sedikit, maka pemasok menetapkan harga yang tidak rendah. Untuk menghindari tingginya biaya, perusahaan harus mempunyai kemampuan untuk meracik pakan dan mengurangi biaya distribusi.

d. Perusahaan sejenis dengan kapasitas lebih besar dan lebih lengkap

Perusahaaan sejenis dalam industri yang sama dapat diangggap sebagai pesaing atau- 
pun mitra dalam bisnis yang dijalankan. Pesaing dalam industri sejenis berperan dalam meningkatkan keunggulan bersaing. Pesaing dapat meningkatkan kemampuan perusahaan dengan diferensiasi sebagai tolok ukur perbandingan (Porter, 1994).

e. Industri produk pengganti

Semua industri menghadapi ancaman substitusi. Substitusi adalah proses suatu produk atau jasa menggantikan yang lain dalam melakukan satu atau beberapa fungsi tertetu bagi pembeli (Porter, 1994).

5. Faktor Peranan Pemerintah

Pemerintah merupakan aspek sangat penting dalam menentukan mutu daya saing suatu bangsa. Peranan pemerintah tercermin melalui kebijakan, regulasi, maupun dukungan terhadap upaya-upaya pengembangan suatu bisnis. Usaha ayam kampung dilindungi oleh pemerintah melalui kebijakan pemerintah dalam Perpres No. 39/2014 bahwa usaha ayam kampung dikembangkan oleh peternakan rakyat.

a. Mengatur tataniaga yang fair

Pemerintah berperan penting dalam mengatur tataniaga bisnis perunggasan. Kasus pada industri unggas ayam ras yang diakibatkan kelebihan pasokan DOC, sehingga menyebabkan ketidakseimbangan supply dan demand. Adanya produk impor yang masuk, telah menekan harga di tingkat peternak. Maka hal ini membutuhkan peran pemerintah mengatur tataniaga, agar terjadi keseimbangan dan peternak tidak dirugikan.

b. Ketersediaan bibit ayam kampung

Usaha pembibitan ayam lokal saat ini kurang berkembang. Pemeliharaan ayam lokal memerlukan waktu 65-70 hari untuk mencapai berat $1 \mathrm{~kg} / \mathrm{ekor}$, sementara ayam ras memerlukan waktu sebulan.

Untuk mendukung kebijakan pemerin-tah dalam pemenuhan kebutuhan pangan dilakukan pengembangan unggas lokal, dimana pemerintah harus menjamin ketersediaan bibit. Perpres Nomor 39/2014, menjelaskan usaha pembibitan hanya boleh dilakukan oleh koperasi dan UKM perlu ditinjau kembali, karena menghambat usaha pembibitan yang membutuhkan dana besar, padahal koperasi dan belum mampu menghasilkan bibit ayam kampung unggul dalam jumlah banyak. Untuk itu diperlukan kebijakan khusus untuk pembibitan misalnya oleh Badan Usaha Milik Negara (BUMN). c. Roadmap dan bussines plan pengembangan ayam kampung

Untuk mendukung pengembangan ayam kampung atau ayam lokal diperlukan roadmap dan bussines plan yang jelas, atau tidak hanya berupa program.

d. Proteksi produk dalam negeri dari ancaman produk impor

Terbukanya pasar unggas dalam negeri telah menimbulkan kekhawatiran peternak ayam, baik ayam ras maupun ayam kampung. Masuknya produk unggas impor menjadi ancaman bagi industri perunggasan. Untuk itu, Pemerintah perlu melindungi peternak dengan mengeluarkan regulasi agar produk impor tidak membanjiri pasar unggas dalam negeri.

e. Fasilitasi ekspor

Untuk menjadi komoditas ekspor, produk ayam kampung harus mempunyai daya saing dan memenuhi standar ekspor. Untuk itu, Pemerintah berperan meningkatkan daya saing ayam kampung dan produknya, walaupun saat ini fasilitasi ekspor ayam kampung belum diperlukan.

6. Faktor Peranan Kesempatan

Faktor kesempatan dapat memberikan dampak nyata, meskipun tidak dapat diprediksi dengan tepat keberadaan dan pergerakannya, misalnya bencana alam, wabah penyakit.

a. Iklim usaha kondusif

Iklim usaha kondusif mampu memberikan kesempatan kepada seluruh pelaku usaha untuk berkembang secara wajar. Dalam iklim usaha yang kondusif, keberhasilan usaha semata-mata dipengaruhi oleh kemampuan pengusaha untuk bersaing dengan pengusaha lain dalam memanfaatkan peluang.

Iklim usaha kondusif memegang peranan penting, agar industri perunggasan mampu meningkatkan efisiensi dan akhirnya berdaya saing dengan perusahaan sejenis dari negara lain. Tambahan biaya yang tinggi untuk birokrasi dan biaya tak terduga dapat mengakibatkan peningkatan biaya produksi (Tangendjaja, 2014b).

b. Kasus flu burung

Flu burung yang terjadi sekitar tahun 2004 berdampak pada banyaknya ayam ras yang mati, sementara ayam kampung relatif bertahan. Keadaan ini mendorong masyarakat untuk mengkonsumsi ayam kampung. 


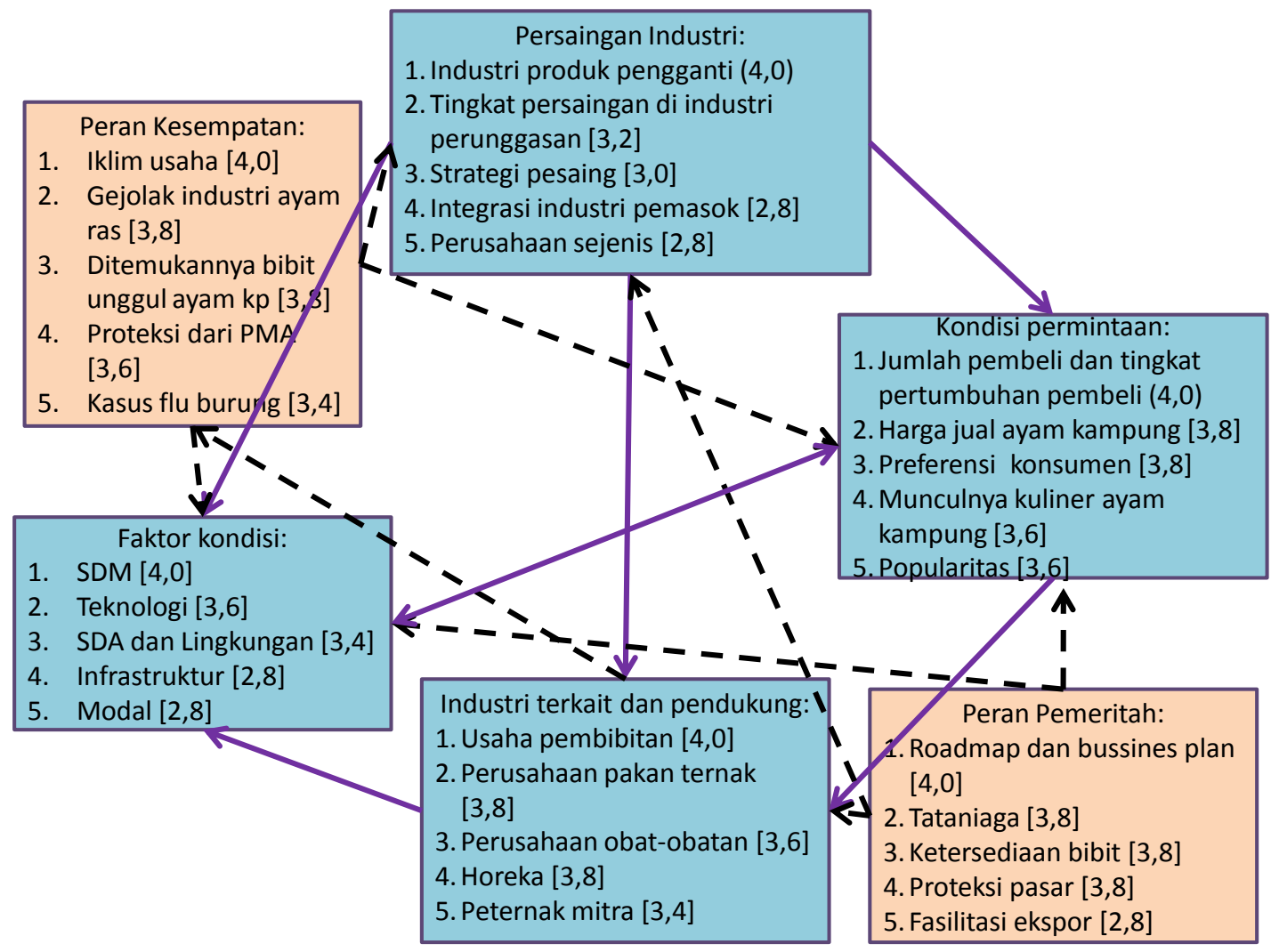

Keterangan:

$\begin{array}{ll}\text { - } & =\text { menunjukkan keterkaitan antara komponen utama yang saling mendukung } \\ & =\text { menunjukkan keterkaitan antara komponen penunjang yang mendukung komponen utama }\end{array}$

Gambar 2. Analisis daya saing industri unggas ayam kampung berdasarkan model Berlian Porter

c. Gejolak industri ayam ras

Terjadinya gejolak industri ayam ras merupakan bencana bagi peternak ayam ras, namun di satu pihak menciptakan kesempatan bagi peternak ayam kampung dalam memanfaatkan peluang tersebut.

d. Ditemukannya bibit ayam kampung

Peternakan ayam kampung selama ini dilakukan secara ekstensif, usaha sampingan, dan mempunyai produktivitas rendah sehingga perkembangannya lambat. Dengan ditemukannya ayam KUB dengan masa panen 65-70 hari, maka peluang usaha budidaya ayam kampung terbuka luas.

e. Proteksi unggas lokal dari perusahaan besar dan PMA

Adanya proteksi usaha pembibitan, persilangan dan budidaya unggas lokal hanya untuk koperasi dan UKM (Perpres 39/2014) telah membuka kesempatan bagi koperasi dan UKM bergerak dalam usaha ayam kampung.

\section{KESIMPULAN}

Faktor-faktor yang memengaruhi daya saing industri unggas ayam Kampung dengan nilai atribut paling tinggi adalah SDM, jumlah pembeli dan tingkat pertumbuhan pembeli, usaha pembibitan, industri produk pengganti, roadmap dan bussines plan pengembangan ayam Kampung, dan iklim usaha kondusif. Faktor yang memengaruhi daya saing dengan nilai atribut paling rendah yaitu: infrastruktur, sumber daya modal, integrasi industri pemasok dan fasilitasi ekspor.

\section{DAFTAR PUSTAKA}

Arli, A. Daryanto, D.S. Hendrawan. 2012. Strategi Peningkatan Daya Saing Rumah Potong Ayam PT XYZ. Jurnal Manajemen Agribisnis. 9 (2): 68-76.

[Bappenas] Badan Perencanaan Nasional. 2013. Analisis Komponen Daya Saing UMKM. Jakarta.

[BPS] Badan Pusat Statistik. 2016. Produksi daging unggas menurut provinsi dan jenis unggas 
(ton), 20011-2015. wwww.bps.go.id diunduh pada tanggal 12 Juni 2016.

Hubeis, M. 2013. Dasar-dasar Manajemen Industri. Inti Prima Promosindo. Jakarta.

M. Najib 2014. Manajemen Strategik dalam Pengembangan Daya Saing Organisasi. Elex Media Komputindo. Jakarta.

[Kementan] Kementerian Pertanian. 2015. Rencana Strategis Kementerian Pertanian RI tahun 2015-2019. Jakarta. Diunduh tanggal $30 \quad$ Mei 2015 dari www.pertanian.go.id.

[Perpres] Peraturan Presiden. Peraturan Presiden RI Nomor 39 Tahun 2014 tentang daftar bidang usaha yang tertutup dan bidang usaha yang terbuka dengan persyaatan penanaman modal. Jakarta. Diunduh 11 Agustus 2015 dari www.hukumonline.com.

Porter, M.E. 1994. Keunggulan Bersaing. Binapura Aksara (Terjemahan). Jakarta.

1998. The Competitive Advantage of

Nations. Macmillan Press Ltd.London.

Saptana, S.T. 2014. Manajemean Rantai Pasok Komoditas Telur Ayam Kampung. Jurnal Manajemen \& Agribisnis. 11(1).

Sartika, T. 2013. Perbandingan morfometrik ukuran tubuh ayam KUB dan Sentul melalui pendekatan analisis diskriminan. Seminar Nasional Teknologi Peternakan dan Veteriner 2013.
Shadid, Y. 2007. From Creativity to Innovation. Policy Research Working Paper 4262. Development Research Group. Washington, D.C: World Bank.

Tangendjaja, B. 2014a. Daya saing produk peternakan: Ceruk pasar. Memperkuat daya saing produk pertanian. Balitbang Kementan. Jakarta.

2014b. Usaha meningkatkan daya saing perunggasan Indonesia. Memperkuat daya saing produk pertanian. Balitbang Kementan. Jakarta.

Utoyo, D.P. 2006. Tataulang Sistem Produksi Perunggasan di Indonesia. Lokakarya Nasional Inovasi Teknologi Dalam Mendukung Usaha Ternak Unggas Berdayasaing. 16(4).

[WEF] World Economic Forum. 2015. The Global Competitiveness Report 2015-2016. World Economic Forum. Geneva.

Widiyastutik, H. Mulyati, E.I.K. Putri. 2010. Analisis Faktor-faktor yang Pengembangan Klaster UMKM Alas Kaki di Kota Bogor yang Berdaya Saing. Jurnal Manajemen \& Agribisnis; 7(1):16-26. Bogor. 